Oxidation and Volatilization of TZM Alloy in Air

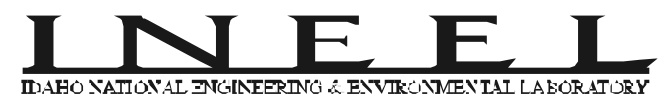
G. R. Smolik
D. A. Petti
S. T. Schuetz

October 10, 2000 - October 15, 2000
$9^{\text {th }}$ International Conference on Fusion Reactor Materials

This is a preprint of a paper intended for publication in journal or proceedings. Since changes may be before publication, this preprint should not be cited reproduced without permission of the author.

This document was prepared as a account of sponsored by an agency of the United States Neither the United States Government nor any thereof, or any of their employees, makes any expressed or impli ed, or assumes any legal liability or responsibility for any third party's use, or the results such use, of any information, apparatus, product process disclosed in this report, or represents that use by such third party would not infringe privately owned rights. The views expressed in this paper not necessarily those of the U.S. Government or sponsoring agency. 


\title{
OXIDATION AND VOLATILIZATION OF TZM ALLOY IN AIR
}

\author{
G.R. Smolik, D.A. Petti, and S.T. Schuetz \\ Idaho National Engineering and Environmental Laboratory \\ P. O. Box 1625, Idaho Falls, Idaho 83415-2218
}

\begin{abstract}
The excellent high temperature strength and thermal conductivity of molybdenum-base alloys provide attractive features for components in advanced magnetic and inertial fusion devices. Refractory metal base alloys react readily with oxygen and other gases, and molybdenum alloys are susceptible to losses from highly volatile molybdenum trioxide $\left(\mathrm{MoO}_{3}\right)$ species. Transport of radioactivity by the volatilization, migration, and re-deposition of $\mathrm{MoO}_{3}$ during a potential accident involving a loss of vacuum or inert environment represents a safety issue. We have experimentally measured the oxidation, volatilization and re-deposition of molybdenum from TZM in flowing air between 400 and $800^{\circ} \mathrm{C}$. Calculations using chemical thermodynamic data for vapor pressures over pure $\mathrm{MoO}_{3}$ and a vaporization mass transfer model correlate well with experimental data between 600 and $800^{\circ} \mathrm{C}$. Partial saturation of $\left(\mathrm{MoO}_{3}\right)$ gas species account for influences of flow rate at $700^{\circ} \mathrm{C}$. Some anomalies in oxidation rate below $650^{\circ} \mathrm{C}$, suggesting that other phases, e.g., $\mathrm{MoO}_{2}$ or other non-stoichiometric oxides may influence oxidation and volatilization processes under some limited conditions.
\end{abstract}

\section{Introduction}

The potential of high temperature strength has motivated much interest in the oxidation behavior of refractory metals. Many of these studies have been oriented toward extremely high temperatures, e.g., up to $1700^{\circ} \mathrm{C}$, often under vacuum or environments with low oxygen activities [1, 2/34. Studies [1,5/6 on molybdenum at lower temperatures in high levels of oxygen report: 1) parabolic rate law at 250 to $450^{\circ} \mathrm{C}, 2$ ) linear behavior above $400^{\circ} \mathrm{C}, 3$ ) a role of $\mathrm{MoO}_{2}$ and other oxides $\left(\mathrm{MoO}_{\mathrm{Z}}\right)$, where $2<\mathrm{Z}<3$, between 450 to $650^{\circ} \mathrm{C}$, and 4) high vaporization of $\mathrm{MoO}_{3}$, mass loss and oxidation rates above $650^{\circ} \mathrm{C}$. We performed this study to explore conditions more typical to future fusion devices and to demonstrate predictive capabilities of a vaporization mass transport model. The model had provided excellent mass transport predications for the highly volatile species produced in tungsten-steam system.[7]

\section{Experimental Procedures}

We tested specimens of TZM alloy between 400 and $800^{\circ}$ in air with flow rates from $10 \mathrm{sccm}$ to $2500 \mathrm{sccm}$. The gas velocities for these flow rates at $700^{\circ} \mathrm{C}$, the INEEL pressure, and the test chamber cross section ranged from 0.033 to 8.32 meters per minute. Oxidation products in the gas stream were re-deposited downstream at temperatures between 800 and $25^{\circ} \mathrm{C}$. The specimens were prepared from a $22-\mathrm{mm}$ diameter bar made by vacuum arc casting and then hot extrusion. The composition was Mo - 99.25 wt $\%$, Ti - $0.50 \mathrm{wt} \%$, $\mathrm{Zr}-0.102$ wt $\%, \mathrm{C}-0.018 \mathrm{wt} \%, \mathrm{Si}-0.0034$ wt $\%$, $\mathrm{Fe}-0.001 \mathrm{wt} \%, \mathrm{Ni}-0.001 \mathrm{wt} \%, \mathrm{O}-0.0009 \mathrm{wt} \%$, and
$\mathrm{N}-0.0005$ wt\%. Disc-shaped specimens of either $1.75-$ or $3.5-\mathrm{mm}$ thickness were sectioned from the bar. Surfaces were polished to a 600 -grit finish. The specimens were tested in a duel furnace arrangement. Dried air preheated to $400^{\circ} \mathrm{C}$ flowed past the specimen in a reaction furnace. The gas stream then passed through a transition zone and a furnace with a low temperature gradient to collect oxidation products transported from the specimen. Samples were weighed before and after testing to obtain mass change. The quartz components were cleaned with 2.9 molar $\mathrm{NH}_{4}(\mathrm{OH})$ to remove the molybdenum oxide products. These solutions were analyzed by inductively coupled plasma-atomic emission spectroscopy (ICP-AES). Sections of 1-in., or 3-in. long quartz tube were used as inserts to line the collection tube and obtain molybdenum distribution. The test matrix with temperatures, times, and flow rates, along with mass changes and total amounts of molybdenum transported as measured by ICP-AES, are shown in Table 1 .

\section{Experimental Results}

Oxidation and molybdenum mass flux rates were calculated from data in Table 1. Mass changes were corrected to allow for concurrent oxygen pick-up and molybdenum volatilization losses. We assumed that the oxidation process essentially produced molybdenum trioxide by the reaction: $\mathrm{Mo}+(3 / 2) \mathrm{O}_{2} \rightarrow \mathrm{MoO}_{3}$. Total mass of molybdenum reacted $\left(\mathrm{M}_{\mathrm{t}}^{\mathrm{Mo}}\right)$ was then determined by the relationship:

$$
\left(\mathrm{M}_{\mathrm{t}}^{\mathrm{Mo}}\right)=\left(\mathrm{M}_{\mathrm{V}}{ }^{\mathrm{Mo}}\right)+(96 / 48)\left[\Delta \mathrm{m}+\left(\mathrm{M}_{\mathrm{V}}{ }^{\mathrm{Mo}}\right)\right] \text {, }
$$

where $\Delta \mathrm{m}$ is the mass change and $\left(\mathrm{M}_{\mathrm{V}}{ }^{\mathrm{Mo}}\right)$ is the amount of volatilized molybdenum as measured by ICP-AES. The results of these calculations are given in Table 2. 
Table 1. Test matrix with mass changes and ICP-AES measurements

\begin{tabular}{|c|c|c|c|c|c|c|c|c|}
\hline Specimen & Temp., ${ }^{\circ} \mathrm{C}$ & $\begin{array}{c}\text { Flow rate, } \\
\mathrm{sccm}\end{array}$ & $\begin{array}{c}\text { Time, } \\
\mathrm{h}\end{array}$ & $\begin{array}{c}\text { Initial } \\
\text { area,cm }\end{array}$ & $\begin{array}{c}\text { Initial } \\
\text { weight, } \mathrm{g}\end{array}$ & $\begin{array}{c}\text { Final } \\
\text { weight, } \mathrm{g}\end{array}$ & $\begin{array}{c}\text { Mass } \\
\text { change, } \mathrm{g}\end{array}$ & $\begin{array}{c}\text { ICP-AES } \\
\text { total, } \mathrm{g}\end{array}$ \\
\hline TZM14 & 400 & 1000 & 24 & 10.345 & 13.6641 & 13.6684 & 0.0043 & $1.5 \mathrm{E}-6(\mathrm{a})$ \\
\hline TZM15 & 500 & 1000 & 24 & 10.369 & 13.8827 & 13.9464 & 0.0637 & $1.02 \mathrm{E}-4$ \\
\hline TZM1 & 500 & 1000 & 24 & 9.101 & 6.6733 & 6.7429 & 0.0696 & $5.97 \mathrm{E}-5$ \\
\hline TZM16 & 550 & 1000 & 24 & 10.402 & 14.0636 & 14.4353 & 0.3717 & $9.04 \mathrm{E}-4$ \\
\hline TZM11 & 602 & 1000 & 8 & 10.235 & 13.1593 & 13.3572 & 0.1979 & $3.25 \mathrm{E}-3$ \\
\hline TZM7 & 599 & 1000 & 24 & 9.136 & 6.8830 & 7.6595 & 0.7765 & $3.56 \mathrm{E}-3$ \\
\hline TZM8 & 650 & 1000 & 8 & 9.123 & 6.8263 & 7.3607 & 0.5344 & $2.51 \mathrm{E}-2$ \\
\hline TZM4 & 699 & 10 & 2 & 8.994 & 6.1262 & 6.1887 & 0.0625 & $4.50 \mathrm{E}-3$ \\
\hline TZM17 & 700 & 10 & 8 & 10.311 & 13.4955 & 13.7485 & 0.2530 & $1.91 \mathrm{E}-2$ \\
\hline TZM5 & 699 & 50 & 2 & 9.111 & 6.7467 & 6.7988 & 0.0521 & $4.55 \mathrm{E}-3$ \\
\hline TZM18 & 700 & 50 & 8 & 10.326 & 13.5565 & 13.7589 & 0.2024 & $5.75 \mathrm{E}-2$ \\
\hline TZM10 & 699 & 100 & 2 & 9.112 & 6.7186 & 6.7441 & 0.0255 & $3.08 \mathrm{E}-2$ \\
\hline TZM6 & 700 & 500 & 2 & 9.075 & 6.4623 & 6.4560 & -0.0063 & $6.49 \mathrm{E}-2$ \\
\hline TZM12 & 700 & 1000 & 2 & 10.343 & 13.6768 & 13.6777 & 0.0009 & $5.43 \mathrm{E}-2$ \\
\hline TZM9 & 700 & 2500 & 2 & 9.069 & 6.5298 & 6.5291 & -0.0007 & $5.67 \mathrm{E}-2$ \\
\hline TZM3 & 750 & 1000 & 1 & 9.056 & 6.4825 & 6.1071 & -0.3754 & $3.46 \mathrm{E}-1$ \\
\hline TZM2 & 800 & 1000 & 1 & 9.150 & 6.9709 & 5.0653 & -1.9056 & $2.22 \mathrm{E}+0$ \\
\hline
\end{tabular}

Table 2. Rates determined from molybdenum oxidation tests

\begin{tabular}{|c|c|c|c|c|c|c|c|c|c|}
\hline Specimen & $\begin{array}{c}\text { Temp } \\
{ }^{\circ} \mathrm{C}\end{array}$ & $\begin{array}{l}\text { Flow } \\
\text { rate, } \\
\text { sccm }\end{array}$ & $\begin{array}{c}\text { Time } \\
\mathrm{h}\end{array}$ & $\begin{array}{c}\text { Total Mo } \\
\text { reacted, } \\
\text { gram }\end{array}$ & $\begin{array}{l}\text { Calculated } \\
\text { recession } \\
\text { rate, } \mathrm{mm} / \mathrm{h}\end{array}$ & $\begin{array}{l}\text { Measured } \\
\text { recession } \\
\text { rate, } \mathrm{mm} / \mathrm{h}\end{array}$ & $\begin{array}{c}\text { Fraction of } \\
\text { reacted Mo } \\
\text { volatilized }\end{array}$ & $\begin{array}{l}\text { Measured } \\
\text { mass flux } \\
\mathrm{g} /\left(\mathrm{m}^{2}-\mathrm{h}\right)\end{array}$ & $\begin{array}{l}\text { Predicted } \\
\text { mass flux } \\
\mathrm{g} /\left(\mathrm{m}^{2}-\mathrm{h}\right)\end{array}$ \\
\hline TZM14 & 400 & 1000 & 24 & 0.0086 & $3.40 \mathrm{E}-5$ & & $1.74 \mathrm{E}-4$ & $6.04 \mathrm{E}-5(\mathrm{a})$ & $1.01 \mathrm{E}-7$ \\
\hline TZM15 & 500 & 1000 & 24 & 0.1277 & $5.04 \mathrm{E}-4$ & & $8.00 \mathrm{E}-4$ & $4.10 \mathrm{E}-3$ & $4.04 \mathrm{E}-4$ \\
\hline TZM1 & 500 & 1000 & 24 & 0.1393 & $6.24 \mathrm{E}-4$ & & $4.43 \mathrm{E}-4$ & $2.73 \mathrm{E}-3$ & $4.04 \mathrm{E}-4$ \\
\hline TZM16 & 550 & 1000 & 24 & 0.7457 & $2.93 \mathrm{E}-3$ & & $1.21 \mathrm{E}-3$ & $3.62 \mathrm{E}-2$ & $1.23 \mathrm{E}-2$ \\
\hline TZM11 & 602 & 1000 & 8 & 0.4053 & $4.85 \mathrm{E}-3$ & & $8.02 \mathrm{E}-3$ & $3.97 \mathrm{E}-1$ & $2.60 \mathrm{E}-1$ \\
\hline TZM7 & 599 & 1000 & 24 & 1.5628 & $6.99 \mathrm{E}-3$ & $6.24 \mathrm{E}-3$ & $2.28 \mathrm{E}-3$ & $1.62 \mathrm{E}-1$ & $2.60 \mathrm{E}-1$ \\
\hline TZM8 & 650 & 1000 & 8 & 1.1434 & $1.54 \mathrm{E}-2$ & & $2.19 \mathrm{E}-2$ & $3.43 \mathrm{E}+0$ & $4.06 \mathrm{E}+0$ \\
\hline TZM4 & 699 & 10 & 2 & 0.1384 & $7.54 \mathrm{E}-3$ & & $3.25 \mathrm{E}-2$ & $2.50 \mathrm{E}+0$ & $6.97 \mathrm{E}-5$ \\
\hline TZM17 & 700 & 10 & 8 & 10.311 & $6.69 \mathrm{E}-3$ & & $3.40 \mathrm{E}-2$ & $2.32 \mathrm{E}+0$ & $6.97 \mathrm{E}-5$ \\
\hline TZM5 & 699 & 50 & 2 & 0.1178 & $6.34 \mathrm{E}-3$ & & $3.86 \mathrm{E}-2$ & $2.50 \mathrm{E}+0$ & $4.57 \mathrm{E}-1$ \\
\hline TZM18 & 700 & 50 & 8 & 0.5769 & $6.85 \mathrm{E}-3$ & & $4.26 \mathrm{E}-2$ & $6.95 \mathrm{E}+0$ & $4.57 \mathrm{E}-1$ \\
\hline TZM10 & 699 & 100 & 2 & 0.1435 & $7.72 \mathrm{E}-3$ & $1.12 \mathrm{E}-2$ & $2.15 \mathrm{E}-1$ & $1.69 \mathrm{E}+1$ & $2.79 \mathrm{E}+0$ \\
\hline TZM6 & 700 & 500 & 2 & 0.1820 & $9.83 \mathrm{E}-3$ & & $3.57 \mathrm{E}-1$ & $3.57 \mathrm{E}+1$ & $2.78 \mathrm{E}+1$ \\
\hline TZM12 & 700 & 1000 & 2 & 0.1645 & $7.80 \mathrm{E}-3$ & & $3.30 \mathrm{E}-1$ & $2.62 \mathrm{E}+1$ & $4.90 \mathrm{E}+1$ \\
\hline TZM9 & 700 & 2500 & 2 & 0.1687 & $9.12 \mathrm{E}-3$ & & $3.36 \mathrm{E}-1$ & $3.13 \mathrm{E}+1$ & $8.61 \mathrm{E}+1$ \\
\hline TZM3 & 750 & 1000 & 1 & 0.2873 & $3.11 \mathrm{E}-2$ & $5.46 \mathrm{E}-2$ & $1.20 \mathrm{E}+0$ & $3.82 \mathrm{E}+2$ & $4.74 \mathrm{E}+2$ \\
\hline TZM2 & 800 & 1000 & 1 & 2.8435 & $3.05 \mathrm{E}-1$ & $3.85 \mathrm{E}-1$ & $7.80 \mathrm{E}-1$ & $2.42 \mathrm{E}+3$ & $3.79 \mathrm{E}+3$ \\
\hline
\end{tabular}

(a) The value reported for $400^{\circ} \mathrm{C}$ is a maximum as established by the detection limit from ICP-AES.

We used these values to determined recession rates $(\mathrm{mm} / \mathrm{h})$ and the fraction of oxidized molybdenum that volatilized. Recession considered as the depth of alloy converted to oxide was calculated using $10.2 \mathrm{~g} / \mathrm{cm}^{3}$ as the density of molybdenum and initial surface area. We used metallography to confirm recession rates $(\mathrm{mm} / \mathrm{h})$ for a limited number of specimens. Average mass flux values were obtained from the sum of the ICP-AES measurements for all system components, the initial surface areas, and the test duration. The above measurements and calculations are listed in Table 2. 


\section{Discussion}

We have plotted the recession rates, fractions of "reacted" metal volatilized, and mass flux rates from Table 2 with respect to reciprocal temperature. The plot for the recession rates is shown in Figure 1. The plot shows a good correlation between rates obtained by the $(\Delta \mathrm{m}+\mathrm{ICP}-\mathrm{AES})$ and metallographic methods. The plot shows a maximum at $650^{\circ} \mathrm{C}$ (the rate at $650^{\circ} \mathrm{C}$ is 2 to 3 times higher than at 600 and $700^{\circ} \mathrm{C}$ ), and then sharply increasing rates from 700 to $800^{\circ} \mathrm{C}$. This trend in oxidation rate is very similar to those observed for the other refractory metals of niobium[2] and tantalum[3]. The irregularities are attributed to various non-stoichiometric phases other than $\mathrm{Nb}_{2} \mathrm{O}_{5}$ or $\mathrm{Ta}_{2} \mathrm{O}_{5}$. Speiser and St. Pierre reported that they sometimes observed a thin $\mathrm{MoO}_{2}$ layer, or an external $\mathrm{MoO}_{3}$ layer with a thin sub-layer of $\mathrm{MoO}_{2}$ or other oxides during the oxidation of molybdenum in air between 450 to $770^{\circ} \mathrm{C}$. The other oxides were reported as being nonstoichiometric, i.e., $\mathrm{MoO}_{\mathrm{z}}$ with " $\mathrm{Z}$ " varying between 2 and 3. The similar characteristics of the refractory metals and the observations above suggest the maximum at $650^{\circ} \mathrm{C}$ in Figure 1 is real and likely caused by different types of oxide. Although we have little data to show kinetic behavior, the two tests at $600^{\circ} \mathrm{C}$ indicate somewhat linear oxidation behavior (Table 2).

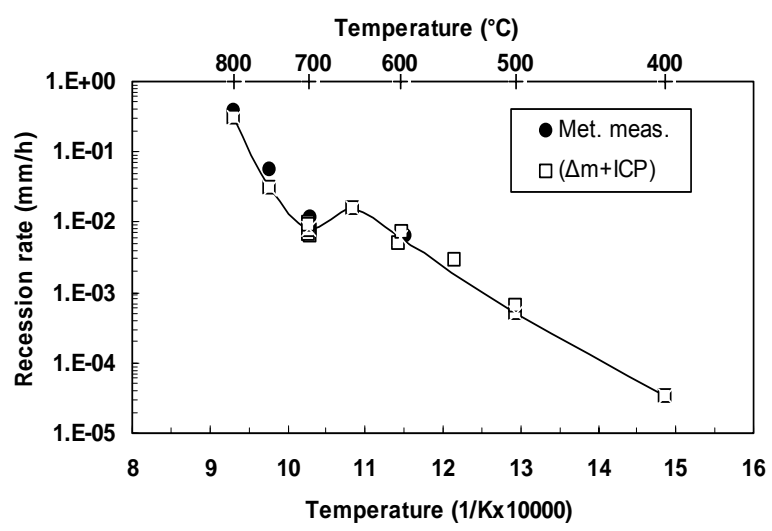

Figure 1. Temperature dependence of recession rate.

The plot of calculated fraction of "oxidized" molybdenum volatilized in Figure 2 show a marked increase above $650^{\circ} \mathrm{C}$. The amount of the oxide volatilized at $700^{\circ} \mathrm{C}$ was generally 20 to 33 percent except for the tests with the lowest flow rates of 10 and $50 \mathrm{sccm}$. Although all $700^{\circ} \mathrm{C}$ tests formed similar amounts of oxides (Table 2), only about one-tenth as much oxide volatilized at the lower flow rates. Our model subsequently presented shows this is the result of partial saturation of the gas phase with the $\mathrm{MoO}_{3}$, effectively reducing the volatilization at low flow rates. Most of the oxide was volatilized at 750 and $800^{\circ} \mathrm{C}$. This corresponds with our metallographic observations

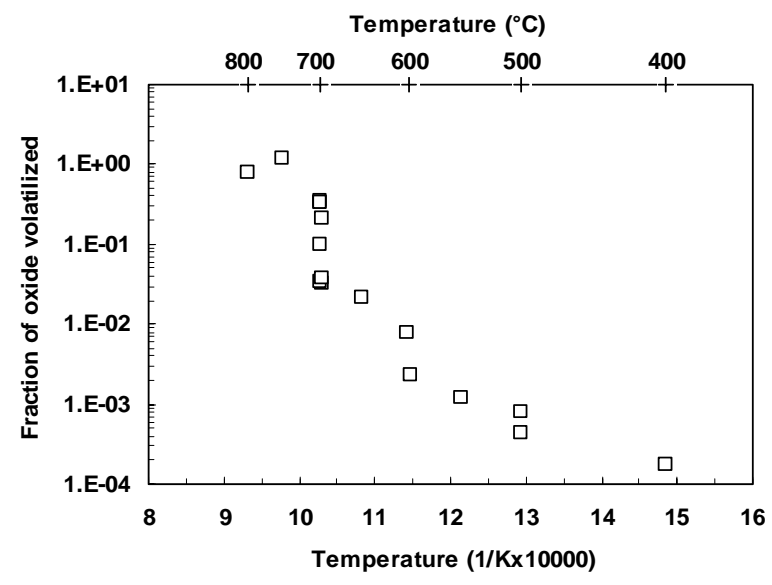

Figure 2. Fraction of $\mathrm{MoO}_{3}$ volatilized at various temperatures.

of only a thin (3 to $10 \mu \mathrm{m}$ ) oxide on these specimens. The high rate of volatilization is apparently linked to the increase in oxidation rate for these two temperatures as shown in Figure 1. Our data agree with that of Gulbransen, et al.11, where all of the oxygen reacted at $800^{\circ} \mathrm{C}$ in 76 torr oxygen and formed volatile oxides. The specimen tested at $800^{\circ} \mathrm{C}$ showed evidence of a molten layer. The sides were smooth and parallel indicative of molten oxide flowing down the specimen. There was a thicker region at the bottom of the specimen displaying some oxides on the surface. This agrees with temperatures reported for the melting points of $\mathrm{MoO}_{3}\left(795^{\circ} \mathrm{C}\right)$ and a $\mathrm{MoO}_{3}-\mathrm{MoO}_{2}$ eutectic $\left(778^{\circ} \mathrm{C}\right)$ 6]. The higher vapor pressure above the melting point would increase volatilization rates, which in turn would increase oxidation rates by removing the oxide barrier.

Insight into the mechanisms governing oxidation and volatilization processes of molybdenum metal at high temperatures $\left(827\right.$ to $\left.1127^{\circ} \mathrm{C}\right)$ is provided by Olander and Schofill[4]. They believe that very thin coatings of $\mathrm{MoO}_{2}$ exist even at high temperatures where rapid evaporation occurs by the overall reaction: $\mathrm{Mo}(\mathrm{s})+$ $3 / 2 \mathrm{O}_{2}(\mathrm{~g})=1 / \mathrm{m}\left(\mathrm{MoO}_{3}\right)_{\mathrm{m}}(\mathrm{g})$. Although the influence of oxygen adsorption on the oxidation behavior of refractory metals has been widely reported, Olander, et al.4 relate the dissociative adsorption of oxygen as the controlling mechanism via the reaction: $\mathrm{O}(\mathrm{ads})+$ $\mathrm{MoO}_{2} \rightarrow \mathrm{MoO}_{3}$ (ads). The available active sites facilitating the adsorption of oxygen in turn depend upon the anion vacancy concentration in the n-type semi-conductor structure of molybdenum dioxide. The above theory may help explain some our data at lower temperatures. The volatilization rate for the 24-h test of $0.162 \mathrm{~g} /\left(\mathrm{m}^{2}-\mathrm{h}\right)$ was less than the rate of $0.397 \mathrm{~g} /\left(\mathrm{m}^{2}-\mathrm{h}\right)$ for the 8 -h test at $600^{\circ} \mathrm{C}$. Perhaps the stoichiometry of 
the oxide changed as the oxide scale grew with time and influenced the volatilization process. It is also possible that the thickened oxide changed the flow pattern thus the volatilization rate.

We used chemical thermodynamic data and a vaporization mass transfer model to predict the mobilization of molybdenum from the specimens tested in air. The model based on the experimental geometry, thermal hydraulic conditions and the vapor pressure of the volatile $\left(\mathrm{MoO}_{3}\right)_{\mathrm{m}}$ over pure molybdenum trioxide was used to predict the mobilization mass flux, J,

$$
\mathrm{J}=\mathrm{h}\left(\mathrm{p}^{\mathrm{Mo}}-\mathrm{p}^{\text {bulk }}\right) / \mathrm{RT}
$$

where

$\mathrm{h}=$ mass transfer coefficient $(\mathrm{m} / \mathrm{s})$,

$\mathrm{p}^{\mathrm{Mo}}=$ partial pressure of volatile $\left(\mathrm{MoO}_{3}\right)_{\mathrm{m}}$ at surface of the specimen,

$\mathrm{p}^{\text {bulk }}=$ partial pressure of volatile $\left(\mathrm{MoO}_{3}\right)_{\mathrm{m}}$ in bulk steam flow.

Since the flow in the experiment is laminar, the mass transfer coefficient is given by [8]:

$$
\mathrm{h}=1.86[\operatorname{Re} \operatorname{Sc}(1 / \mathrm{d})]^{1 / 3} \mathrm{D} / \mathrm{d}
$$

$\mathrm{D}$ is the diffusion coefficient of $\left(\mathrm{MoO}_{3}\right)_{\mathrm{m}}$ in air based on classic Chapman-Eskong theory 8 and $\mathrm{Re}$ is the Reynolds number, Sc is the Schmidt number, and 1 and $\mathrm{d}$ are the length and diameter of the test chamber. The partial pressure of $\left(\mathrm{MoO}_{3}\right)_{\mathrm{m}}$ is determined as an effective value for the various polymeric forms of $\left(\mathrm{MoO}_{3}\right)$ existing at different temperatures over pure solid or molten $\mathrm{MoO}_{3}$. Vapor pressures for the various polymer species were obtained from the HSC thermochemical computer code 9 . Surface to bulk pressures of $\left(\mathrm{MoO}_{3}\right)_{\mathrm{m}}$ are corrected for the partial saturation of $\left(\mathrm{MoO}_{3}\right)_{\mathrm{m}}$ in the bulk flow by Eq. 3, where $\mathrm{Q}$ is the volumetric flow rate of air $\left(\mathrm{m}^{3} / \mathrm{s}\right)$.

$$
\left(\mathrm{p}^{\text {bulk }} / \mathrm{p}^{\mathrm{Mo}}\right)=[1-\exp (-\mathrm{hA} / \mathrm{Q})]
$$

Mass flux values of molybdenum predicted from the model are listed in Table 2. Predicted values are plotted in Fig. 3 along with the experimental data. Calculations from the model agree quite well with experimentally derived mass flux measurements from 600 to $800^{\circ} \mathrm{C}$. Although Eq. 3 predicts the decreasing trend of mass flux with lower flow rates at $700^{\circ} \mathrm{C}$ as shown in Table 2, experimental values are somewhat higher. We observed the growth of needle-, or ribbonlike, crystals on these specimens. Some of these crystals spalled off and remained in the reaction chamber contributing to mobilized mass. Measured values of mass flux were somewhat higher than the model predictions below $600^{\circ} \mathrm{C}$. We believe that some mobilization has occurred at low temperatures from a volatile hydroxide, $\mathrm{MoO}_{2}(\mathrm{OH})_{2(\mathrm{~g})}$, formed from water vapor in ambient air which leaked into the test system. Speiser and St. Pierre 6 reported on the occurrence of this mechanism. Our data with an inflection in volatilization rate near $600^{\circ} \mathrm{C}$ resembles that shown by Simnad and Spilners [5]. They reported activation energies of $53.0 \mathrm{kcal} / \mathrm{mole}$ and $89.6 \mathrm{kcal} / \mathrm{mole}$ below and above $650^{\circ} \mathrm{C}$, which likely reflect the volatilization processes of $\mathrm{MoO}_{2}(\mathrm{OH})_{2(\mathrm{~g})}$ and $\left(\mathrm{MoO}_{3}\right)_{\mathrm{m}}$, respectively.

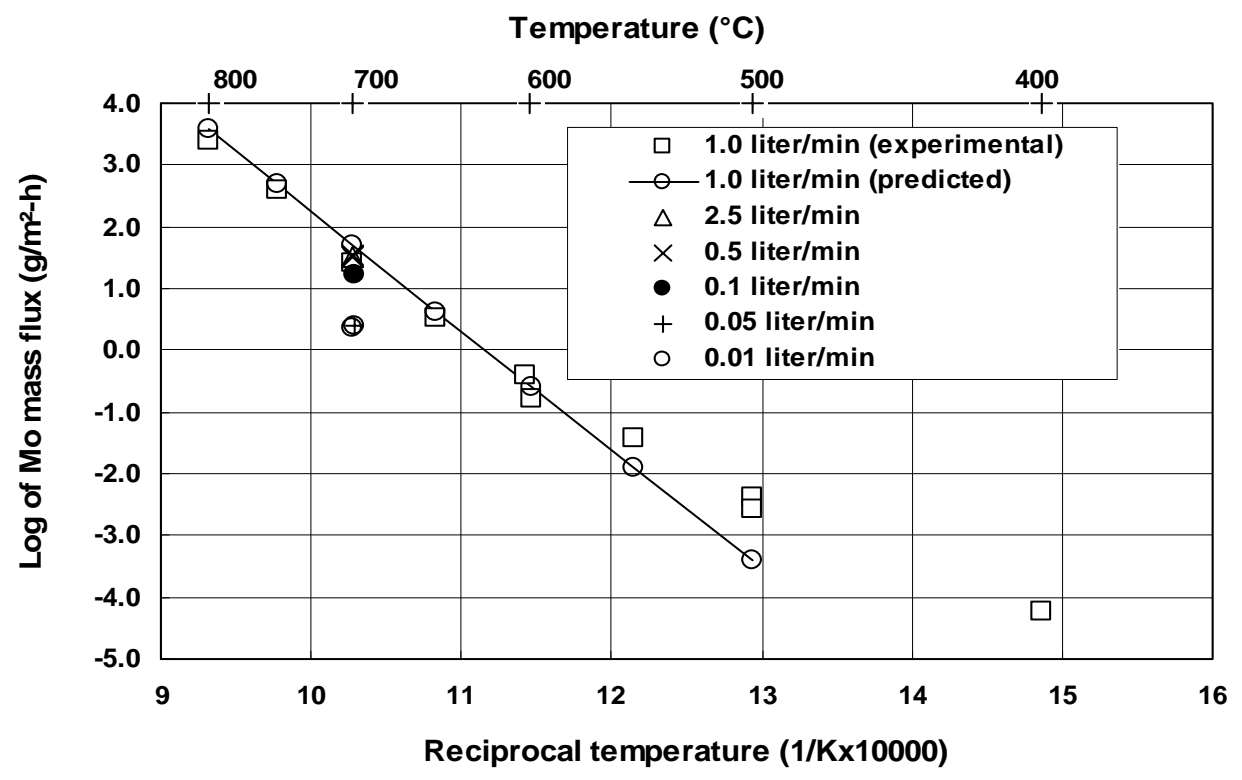

Figure 3. Measured and predicted rates of molybdenum mass flux. 


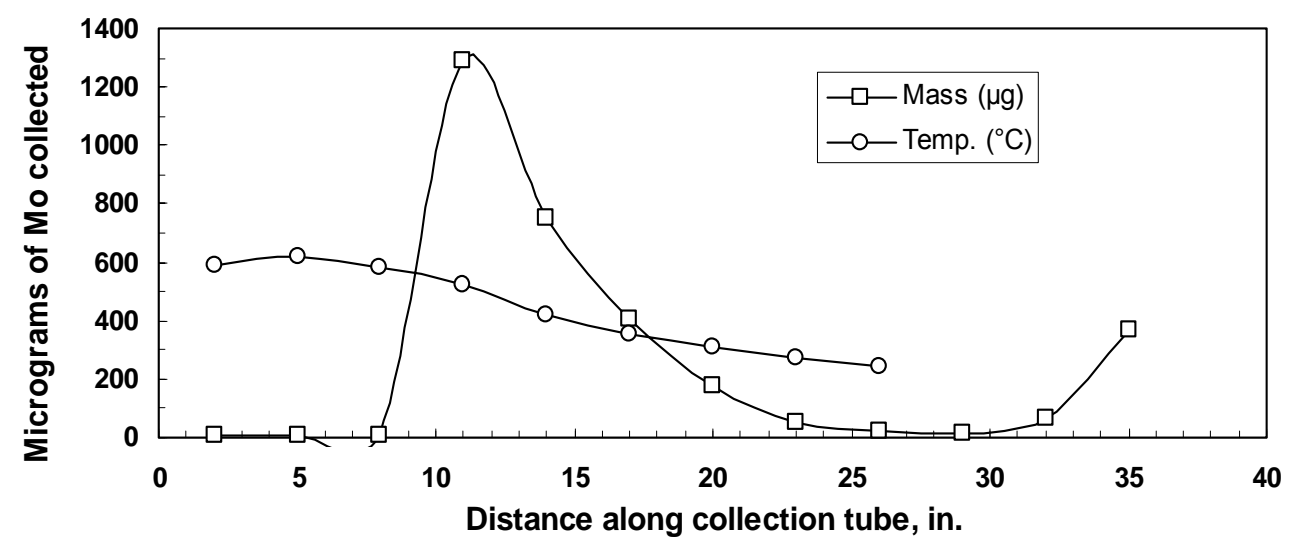

Figure 4. Distribution of re-deposited molybdenum for $600^{\circ} \mathrm{C}$ test.

An example of molybdenum distribution deposited in the temperature gradient downstream is shown in Figure 4 for a $600^{\circ} \mathrm{C}$ test. A maximum exists about 28 $\mathrm{cm}$ (11 in.) downstream at temperatures of 550 to $600^{\circ} \mathrm{C}$. We observed a high density of light yellow, needle-like crystals at such locations. Other powdery material was deposited on the walls of the tube and in the quartz wool filter at the end. Scanning electron microscopy showed that some of this material consisted of agglomerated sub-micron size particles. The crystals and small particles support our model predictions, i.e., vapor transport contributing to crystal growth but also particle nucleation, growth and agglomeration occurring due to some gas phase saturation. Analyses of the re-deposition processes will be presented in the future.

\section{Conclusions}

We have observed good correlation between experimental volatilization rates and those predicted by our mass transport model using thermodynamically derived vapor pressures of $\left(\mathrm{MoO}_{3}\right)$ polymeric species over pure $\mathrm{MoO}_{3}$ from 600 to $800^{\circ} \mathrm{C}$. Spalled oxide produced somewhat higher mobilization rates than predicted for low flow-rate tests at $700^{\circ} \mathrm{C}$, while $\mathrm{MoO}_{2}(\mathrm{OH})_{2(\mathrm{~g})}$ volatilization from small concentrations of water vapor from ambient air contributed to mobilization below $600{ }^{\circ} \mathrm{C}$. The oxidation rate $(\mathrm{mm} / \mathrm{h})$ as indicated by recession, i.e., the amount of metal reacted, showed an increasing trend to $650^{\circ} \mathrm{C}$, then a slight decrease, and then sharply higher rates due to high volatilization. This trend is observed with other refractory metals and has been associated with different oxide types. We believe our study shows that the model from 600 to $800^{\circ} \mathrm{C}$ and the oxidation rates from 400 to $800^{\circ} \mathrm{C}$ are appropriate for representing behavior of TZM in air.

\section{Acknowledgments}

This work is supported by the U.S. Department of Energy, Office of Energy Research, under the DOE Idaho Operations Contract DE-AC07-94ID13223. The authors wish to acknowledge the contributions of J. D. Christian and D. L. Hagrman for their help with vapor pressure properties and interpretation of the vaporization mechanisms, respectively.

\section{References}

[1] Gulbranson, et al., J. Electrochemical Soc., 110, (1963) 952-959.

[2] J. N. Ong, Jr. and W. M Fassell, Jr., Corrosion, 18, (1962) 382t-389t.

[3] Kofstad, P., J. Inst. of Metals, 90, (1962) 253-264.

[4] D. R. Olander and J. L. Schofill, Jr., Metallurgical Transactions, 1, (1970) 2775-2784.

[5] M. Simnad and A. Spilners, J. Metals, 7, (1955) 1011-1016.

[6] R. Speiser and G. R. St. Pierre, in The Science ad Technology of Tungsten, Tantalum, Molybdenum, Niobium and Their Alloys ed. by N. E. Promisel, Pergamon Press (1964) 289-330.

[7] D. A. Petti, G. R. Smolik, and K. A. McCarthy, Tungsten Mobilization During Steam Between 400 and $1200^{\circ} \mathrm{C}, 20^{\text {th }}$ SOFT, Sept. 9-11,1998, Marseille, France 1483-1486.

[8] R. B. Bird, W. E. Steward and E. N. Lightfoot, "Transport Phenomena", John Wiley and Sons (1960).

[9] A. Roine, Outokumpu HSC Chemistry for Windows, Version 2.0 (1994). 